Copyright (C) 2020 University of Bucharest Printed in Romania. All rights reserved

ISSN print: $1224-5984$

ISSN online: $2248-3942$
Rom Biotechnol Lett. 2020; 25(6): 2070-2078

doi: $10.25083 / \mathrm{rbl} / 25.6 / 2070.2078$

Received for publication, April, 13, 2020

Accepted, September, 14, 2020

Original paper

\title{
Test of some insecticides for Tanymecus dilaticollis Gyll. control, in organic agriculture conditions
}

\section{MARIA TOADER ${ }^{*}$, EMIL GEORGESCU ${ }^{2}$, ALINA MARIA IONESCU ${ }^{1}$, COSMIN ȘONEA ${ }^{1}$}

${ }^{1}$ University of Agronomic Sciences and Veterinary Medicine of Bucharest, Romania

${ }^{2}$ National Agricultural Research and Development Institute Fundulea, Călarași, Romania

\begin{abstract}
The research focus to study the effectiveness of some active substances of insecticides for the control of maize leaf weevil (Tanymecus dilaticollis) in the organic agriculture conditions at the Plant Protection Laboratory of National Agricultural Research and Development Institute Fundulea (NARDI). In experiment, were used some permitted active substances in organic farming, according to Annex 2 of Regulation 889/2008 for the pests control, respectively: neem oil, spinosad and Bacillus thuringiensis for treatment of seeds and the same products applied in vegetation period of maize plant. The highest value of saved plants was $82.78 \%$ for treatment of maize seeds with neem oil and for spinosad applied in vegetation with $79.78 \%$. The attack intensity had the highest level in the untreatment variant (5.90) and the lowest was in the variant of seed treated with neem oil (3.72). In conclusion, this experiment demonstrates the good efficacy of these products, that could be an alternative method for pest control in organic farming, in Romania.
\end{abstract}

Keywords Effectiveness of insecticides, maize, organic agriculture, pest control, Tanymecus dilaticollis.

To cite this article: TOADER M, GEORGESCU E, IONESCU AM, ȘONEA C. Test of some insecticides for Tanymecus dilaticollis Gyll. control, in organic agriculture conditions. Rom Biotechnol Lett. 2020; 25(6): 2070-2078. DOI: 10.25083/rbl/25.6/2070.2078

*Corresponding author: MARIA TOADER, University of Agronomic Sciences and Veterinary Medicine of Bucharest, 59 Mărăşti Boulevard, District 1, Bucharest, 011464, Romania

E-mail: mirelatoadervali@yahoo.com 


\section{Introduction}

Organic agriculture has the fastest growing development in the food sector today, with a rate of organic food sales between $20-25 \%$ per year (FAO [4]). The total organic area reaches over 45 million hectares, in 2018 (WILLER \& al [23]). In Romania, organic agriculture means over 326 thousand ha. The cereals are the most important crops, with around 114 thousand ha, respectively, the maize crop occupies the largest surface, over 70 thousand ha (MARD [15]).

An essential factor for maize cultivation is the optimal density of plants in the strand to allow for high quality and economically efficient production. The maize leaf weevil, Tanymecus dilaticollis Gyll. (Curculionidae Family) is the most important pest of maize in Romania. This insect is a polyphagous pest and causes considerable damage in other crops such as sunflower, sugar beet, sorghum, soybean, lucerne (PAULIAN \& al [18]; POPOV $\&$ al [19], GEORGESCU \& al [6]).

Maize plants are attacked during emergence time and up to the 4-leaf stage when they can be roasted in the maize cornet area; for 2-3 leaf stage, adults eat plants from the cornet, causing the mass destruction of the crop, which requires its re-sowing (PAULIAN [17]). Due to the attack, the leaves at the base of the plant can be circularly perforated.

Maize plants past the 4-5 leaf stage are no longer the source of food for the pest that passes on other spontaneous plants. If untreated maize seeds are sown, damage can be very high and maize crop can be compromised $100 \%$ (BARBULESCU \& al [1]).

Even if the seed is treated with specific products, the crop must be monitored permanently, because in a strong attack, the losses can be massive. Until the 5-leaf stage, the crop should be monitored daily or at least once every two days to see if the treatment has worked, if there are any living pests on the plant or if the second or third treatment is needed (GEORGESCU \& al [7]).

After several years of use of chemical pesticides, today's agriculture is increasingly focusing on finding milder solutions to the environment in pest control actions. The resistance of cultivated species to conventional insecticides is well known, but disease management caused by insects is often neglected. Bio insecticides are the best remedies in situations where farmers have failed to control insects, despite the use of high doses of chemical pesticides. In contrast to these, bio insecticides offer long-term protection to both the crop and the soil.

Pests of maize crops can cause multiple inconveniences. They infest crops and reduce the yield of total agricultural production, but also its health. When dealing with pests, such as Tanymecus dilaticollis, most farmers use pesticides that can negatively impact their health, pollute water resources through leaks, and, if pesticides are used abusively or incorrectly, they can kill plants. Finding new ways to get rid of pests without requiring the use of chemicals has become a priority for many conventional farmers and, priority for organic farming. Pest management in organic farming is achieved by using appropriate cropping techniques, biological control, and natural pesticides (mainly extracted from plant or animal origins).

On the other hand, harmfulness of Tanymecus dilaticollis has increased in the last years in the Romania. Adults consume leaves margins and destroy apical meristems. Control measures include limiting maize production to 2 or less years in a crop rotation. Maize and sunflower are necessary to alternate with cereals in crop rotation (AGROATLAS [14]). According data of "Journal General de l'Europe", in the specific pedoclimatic conditions of South and South East of Romanian agricultural land, around one million ha of maize and sunflower emerging crops are exposed every spring to this soil insect attack (JOURNAL GENERAL DE L'EUROPE [9]). T. dilaticollis is amongst the most important pests on maize and sunflower in especial in Eastern and Central Europe (GERGINOV [5]; KACSÓ [10]; KESZTHELYI \& al [11]; KIRKOV [12]; KRUSTEVA \& al [13]; POPOV, BARBULESCU [19]; SÁRINGER, TAKÁCS [20]) and can also damage sugar beet, wheat, barley, oat, bean, tobacco, watermelon and alfalfa (ČAMPRAG \& al [2]).

Currently, various agronomic (soil tillage, crop rotation, proper time of sowing, conditions favoring rapid seedling development and plant density) and chemical (seed-dressing formulations, spraying with pyrethroids, organophosphates, phenylpyrazoles and nereistoxin analogues) measures are applied to control $T$. dilaticollis (BARBULESCU \& al [1]; ČAMPRAG \& al [2]; KIRKOV [12]; KRUSTEVA \& al [13]; VOINESCU [22]). To reduce the large yield losses caused by adults and environmental risks connected with broad spectrum insecticide application, new biocontrol products need to be developed and included in integrated pest management (IPM) schemes for this pest.

According to Guidelines on Good Plant Protection Practice of European and Mediterranean Plant Protection Organization [3], the basic strategies includes various cultural methods can reduce Tanymecus dilaticollis population and damage: crop rotation, time of sowing, conditions favouring rapid seedling development and plant density. It is important to assess the insect population in autumn before overwintering and then in spring when the plants start to grow. Insecticide spray application is the main control method; nevertheless, preventive systemic seed-dressing formulations may be used as well.

The importance of this experiment derives from the priority of farmers to find new viable solutions to control the attack of this important pest in maize crops, which respects the principles of organic farming and ensures the protection of the crop under conditions of economic efficiency. Also, these results could be an alternative for conventional farmers in the actual context of sustainable use of pesticides and restricting the application of chemical pesticides. 


\section{Materials and Methods}

\section{The design of the experiment}

These researches continue a serie that started at NARDI Fundulea, in 2014. The research was carried out in the Experimental Field of Plant Protection Department, National Agricultural Research and Development Institute Fundulea (NARDI), Calarasi County, Romania, in 20162018 periods.

The experimental field of NARDI Fundulea is located in a climatic region of the plain, with an average annual temperature of $11.3^{\circ} \mathrm{C}$. Between April and October average temperature is over $17.34^{\circ} \mathrm{C}$; and in June-August the temperature exceeds $20^{\circ} \mathrm{C}$. Annual precipitations generally range from 400 to $530 \mathrm{~mm}$. The spring season is poorly shaped, the transition from spring to summer is short, and from autumn to winter it is longer. Monthly average temperatures for the experimentation period (2016-2018) as well as multi-annual averages are shown in Table 1. From the examination of the data in the table it is noted that the multiannual average (in the last 50 years) for JanuaryOctober was $12.34^{\circ} \mathrm{C}$. The months with the highest temperatures are July and August, with $22.5^{\circ} \mathrm{C}$ and $21.9^{\circ} \mathrm{C}$ respectively, and the lowest value (the coldest month) is recorded in January, with $-2.4^{\circ} \mathrm{C}$. Analyzing the average data for the period 2016-2018, it can be seen that the average temperature for the January-October period was $13.82^{\circ} \mathrm{C}$, higher than $1.48^{\circ} \mathrm{C}$ compared to the multiannual average. The spring was also very early, with a difference from the $2.4^{\circ} \mathrm{C}$ multiannual average for February and $0.8^{\circ} \mathrm{C}$ for March. The warmest month was August with an average temperature of $24.1^{\circ} \mathrm{C}$, means $2.2^{\circ} \mathrm{C}$ higher than the multiannual average of this month. At a slight difference was the temperature in June, by $1.8^{\circ} \mathrm{C}$ compared to the multiannual average.

Table 1. Temperatures recorded at NARDI Meteorological Station and multiannual averages $\left({ }^{\circ} \mathrm{C}\right)(2016-2018)$

\begin{tabular}{|l|c|c|c|c|c|c|c|c|c|c|c|}
\hline \multirow{2}{*}{ Year } & \multicolumn{9}{|c|}{ Month } & \multirow{2}{*}{ Average } \\
\cline { 2 - 13 } & I & II & III & IV & V & VI & VII & VIII & IX & X & \\
\hline 2016 & -4.3 & 6.2 & 7.3 & 14.0 & 16.1 & 22.9 & 24.1 & 23.9 & 19.1 & 10.3 & 13.96 \\
\hline 2017 & -0.2 & 2.2 & 4.4 & 13.8 & 16.8 & 21.6 & 23.6 & 23.3 & 16.6 & 9.0 & 13.11 \\
\hline 2018 & -2.4 & -0.3 & 4.7 & 15.8 & 19.4 & 22.6 & 22.8 & 25.0 & 17.2 & 19.1 & 14.39 \\
\hline Average (2016-2018) & -2.3 & 2.7 & 5.5 & 14.5 & 17.4 & 22.4 & 23.5 & 24.1 & 17.6 & 12.8 & 13.82 \\
\hline Multiannual average & -2.4 & -0.3 & 4.7 & 11.1 & 16.9 & 20.6 & 22.5 & 21.9 & 17.2 & 11.2 & 12.34 \\
\hline $\begin{array}{l}\text { Deviations from the } \\
\text { multiannual average }\end{array}$ & -0.1 & 2.4 & 0.8 & 3.4 & 0.5 & 1.8 & 1.0 & 2.2 & 0.4 & 1.6 & 1.48 \\
\hline
\end{tabular}

Between 2016 and 2018, the sum of rainfalls between January and October (Table 2) averaged $555.6 \mathrm{~mm}$, with a surplus over the multi-annual average of $27.6 \mathrm{~mm}$; however, due to the inadequate rainfall distribution, droughts occurred in the summer months. For the sowing period of maize there was a deficit of about $28 \mathrm{~mm}$ from the average of the area. It is noted in April 2018, with a deficit of $56 \mathrm{~mm}$ from multiannual average and June 2018 with a $74 \mathrm{~mm}$ surplus over the average.

Table 2. Rainfalls recorded at NARDI Meteorological Station and multiannual averages (mm) (2016-2018)

\begin{tabular}{|l|c|c|c|c|c|c|c|c|c|c|c|}
\hline \multirow{2}{*}{ Year } & \multicolumn{9}{|c|}{ Month } & Average \\
\cline { 2 - 13 } & I & II & III & IV & V & VI & VII & VIII & IX & X & \\
\hline 2016 & 59.0 & 72.3 & 72.2 & 71.5 & 52.6 & 50.1 & 46.2 & 59.0 & 72.3 & 72.2 & 627.4 \\
\hline 2017 & 53.9 & 31.1 & 85.1 & 18.1 & 36.7 & 23.3 & 77.4 & 59.3 & 15.0 & 111.6 & 511.5 \\
\hline 2018 & 57.6 & 56.8 & 70.4 & 3.0 & 42.8 & 146.2 & 83.6 & 5.0 & 31.8 & 30.7 & 527.9 \\
\hline Average (2016-2018) & 56.8 & 53.4 & 75.9 & 30.9 & 44.0 & 73.2 & 69.1 & 41.1 & 39.7 & 71.5 & 555.6 \\
\hline Multiannual average & 33.0 & 31.1 & 37.5 & 59.0 & 72.3 & 72.2 & 71.5 & 52.6 & 50.1 & 46.2 & 525.5 \\
\hline $\begin{array}{l}\text { Deviations from the } \\
\text { multiannual average }\end{array}$ & 23.8 & 22.3 & 38.4 & -28.1 & -28.3 & 1.0 & -2.4 & -11.5 & -12.9 & 25.3 & 27.6 \\
\hline
\end{tabular}

The soil type in experimental field was cambic chernozem (GEORGESCU \& al [8]).

Regarding the hydro-physical and chemical properties of the Fundulea cambic chernozem, we mention the following: a clayey texture on horizon $\mathrm{A}$ and on the other horizons; apparent density values (1.19 in A horizon and 1.40-1.44 in deep sub-horizons); the total porosity (56\% in Ap and 46-48\% in deep sub-horizons), the aeration
(18\% in Ap and 10-13\% in deep sub-horizons), indicating relatively loose and moderately tilled soil, wilting coefficients moderate ranging from $10.9-11.9 \%$ in horizon $\mathrm{A}$, $10.3-10.8 \%$ in horizon $\mathrm{AB}$ and below $8.8-10.3 \%$ in horizon $\mathrm{Bv}$ and useful water capacity (32\% in Ap and $24-26 \%$ in deep sub-horizons) small-medium. Also, the hydraulic permeability of the soils from experimental field is good $(15.6-21.1 \mathrm{~mm} / \mathrm{h})$ in horizon A $(15.6-21.1 \mathrm{~mm} / \mathrm{h})$ and 
medium in the deep horizons $(10.4-12.2 \mathrm{~mm} / \mathrm{h})(\mathrm{PARTAL}$ $\&$ al [16]).

From an agrochemical point of view, the soil from Fundulea is characterized by a weak acid $(\mathrm{pH})$ reaction (6.3-6.8) in horizon A and neutral - weak alkaline (7.2-7.4) in the horizons $\mathrm{AB}$ and $\mathrm{Bv}$, as well as a total capacity of high cation exchange (18.8-19.7 me/100 g soil), and a very high degree of saturation with bases (V) (88.7-100\%) over the whole soil profile, corresponding to the adsorptive complex of the soil (clay + humus), (PARTAL \& al [16]).

The supply of the chernozem from Fundulea with nutrients is also good, especially in the sub-horizon A $(0-15 \mathrm{~cm}): 3 \%$ humus, $0.18 \%$ total Nitrogen, $0.08 \%$ Phosphorus total, $28 \mathrm{ppm}$ phosphorus and 87-98 ppm Potassium (PARTAL \& al [16]).

The hybrid used in the research was Olt, FAO 450, originated from NARDI Fundulea.

The experiments have been placed in maize monoculture, with pea strips for the delimitation of plots.

The distance between the rows was $70 \mathrm{~cm}$ and the density of sowing was 60816 seeds/ha.

The soil tillage consisted of a plow to $28-32 \mathrm{~cm}$ depth in September, after harvest of maize. Tillage has been used over to control weeds, to incorporate previous crop residues, and to prepare the seedbed.

In the spring, the plot was disking twice, prepared the seedbed and sowing. Sowing was done manually, for a better density of plants. Also, the weed control has been manualy, to ensure a very good management of weed control.

The experimental variants were as follows:

- Tree variants for seeds treatment:

- V1 - untreated control;

- V2 - seed treatment with neem oil (commercial product was Neem oil, at a dose of $2.5 \mathrm{~mL} / 250 \mathrm{~g}$ of seed);

- V3 - seed treatment with spinosad (commercial product was Laser $240 \mathrm{SC}$, at a dose of $2.5 \mathrm{~mL} / 250 \mathrm{~g}$ of seed);

- V4 - seed treatment with 54\% Bacillus thuringiensis (commercial product was Bactospeine DF, at a dose of $0.01 \%$ );

- Tree variants for vegetation period:

- V5 - vegetation treatment with neem oil (commercial product was Neem oil at a dose of $250 \mathrm{~mL} / \mathrm{ha}$ );

- V6 - vegetation treatment with spinosad (commercial product was Laser $240 \mathrm{SC}$, at dose $250 \mathrm{~mL} / \mathrm{ha}$ );

- V7 - vegetation treatment with 54\% Bacillus thuringiensis (commercial product was Bactospeine DF, at a dose of $0.01 \%$ ).

These products are in accordance with Regulation (CE) 889/2008 of applying Regulation 834/2007, Annex II and are accepted as input in the organic agriculture.

\section{Method of experimentation}

After the emergence of maize plants, after (8-10 days after sowing) when the rows became visible, we were marked 20 plants on the four central rows on each experimental plot. When maize plants reached the 4-leaf stage (BBCH 14) the intensity of the attack was determined. The insecticides used for the vegetation treatment were applied after marked maize plants.

This scale attack intensity ranged from: 1 - unattacked plant to 9 - plant completely destroyed.

We noted:

Note 1: plant not attacked;

Note 2: plant with 2-3 simple bites on the leaf edge;

Note 3: plants with bites or clips on leaf edge;

Note 4: plants with leafs chafed in proportion of $25 \%$;

Note 5: plants with leafs chafed in proportion of 50\%;

Note 6: plants with leafs chafed in proportion of $75 \%$;

Note 7: plants with leafs chafed almost at the level of the stem;

Note 8: plants with leafs completely chafed and beginning of the stem destroyed;

Note 9: destroyed plants, with stem chafed close to soil level (PAULIAN [17]; POPOV, BARBULESCU \& al [19]; GEORGESCU \& al [8]; TOADER \& al [21]).

At 30 days of emergence, the percentage of plants saved (\%) was determined by counting the plants on the entire plot and reporting them to the number of seeds sown per plot.

Data were statistically analyzed by analysis of variance and the Student Neuman Keuls (SNK) test with the ARM 8.5 program.

\section{Results and Discussion}

\section{The number of emerged plants}

Between 2016 and 2018, in the control variant, which did not treat of the seed and no treatments were applied in vegetation, the number of emerged plants was smaller, from 3.65 to $3.85 \mathrm{pl} / \mathrm{m}^{2}$, by comparison with other variants. For the variants that used seed treatment with neem oil, the emerged plants were, in average $5.92 \mathrm{pl} / \mathrm{m}^{2}$, for all three years of experimentation. Results of $5.67 \mathrm{pl} / \mathrm{m}^{2}$ were also recorded in Spinosad variant treatments in vegetation, and also for seed treatment with Bacillus turingiensis, with $5.08 \mathrm{pl} / \mathrm{m}^{2}$.

Under the conditions of year 2016, it was found that the maize plant density at emergence was low for the untreated variant $\left(3.70 \mathrm{pl} / \mathrm{m}^{2}\right)$. In the other experimental variants, the maize plant density, at emergence, was between 4.0 and $6.0 \mathrm{pl} / \mathrm{m}^{2}$.

In 2017, the maize plant density had the lowest value of $3.85 \mathrm{pl} / \mathrm{m}^{2}$ in the control variant, and the largest for the seeds treatment and vegetation variants with the neem oil, $5.92 \%$ and also for spinosad in vegetation, $5.67 \mathrm{pl} / \mathrm{m}^{2}$. For 2018, the efficacy of seed treatment with neem oil was confirmed again, with a density of $6.00 \mathrm{pl} / \mathrm{m}^{2}$. Regarding vegetation treatmant, it was noticed spinosad with $5.75 \mathrm{pl} / \mathrm{m}^{2}$ and Bacillus turingiensis cu $5.50 \mathrm{pl} / \mathrm{m}^{2}$ (Table 3). 
Table 3. Number of emerged plants ( $\left.\mathrm{pl} / \mathrm{m}^{2}\right)(2016-2018)$

\begin{tabular}{|l|l|l|l|l|l|}
\hline \multirow{2}{*}{$\begin{array}{l}\text { Treatment } \\
\text { application }\end{array}$} & Active substance/commercial product & \multicolumn{3}{|c|}{ Years } & \multirow{2}{*}{ Average } \\
\cline { 2 - 6 } & & $\mathbf{2 0 1 6}$ & $\mathbf{2 0 1 7}$ & $\mathbf{2 0 1 8}$ & \\
\hline Untreatment plot & Control & 3.70 & 3.85 & 3.65 & 3.73 \\
\hline \multirow{4}{*}{ Seed treatment } & Neem oil, 2.5 mL/250 g & 6.00 & 5.75 & 6.00 & 5.92 \\
\cline { 2 - 6 } & Spinosad, 2.5 mL/250 g & 4.00 & 4.30 & 4.10 & 4.13 \\
\cline { 2 - 6 } & 54\% Bacillus thuringiensis, 0.01\% & 5.50 & 5.25 & 4.50 & 5.08 \\
\hline \multirow{2}{*}{$\begin{array}{l}\text { Vegetation } \\
\text { treatment }\end{array}$} & Neem oil, 250 mL/ha & 5.50 & 5.75 & 5.00 & 5.42 \\
\cline { 2 - 6 } & Spinosad, 250 mL/ha & 6.00 & 5.25 & 5.75 & 5.67 \\
\cline { 2 - 6 } & 54\% Bacillus thuringiensis, 0.01\% & 5.00 & 4.75 & 5.50 & 5.08 \\
\hline LSD P=.05 & 0.300 & 0.300 & 0.275 & 0.395 \\
\hline Standard Deviation (SD) & 0.202 & 0.202 & 0.185 & 0.266 \\
\hline Variation coefficient (CV) & 3.960 & 3.960 & 3.720 & 5.390 \\
\hline Replicate F & 1.937 & 1.937 & 0.965 & 0.706 \\
\hline Replicate Prob (F) & 0.1598 & 0.1598 & 0.4308 & 0.5606 \\
\hline Treatment F & 83.349 & 83.349 & 60.480 & 43.757 \\
\hline Treatment Prob (F) & 0.0001 & 0.0001 & 0.0001 & 0.0001 \\
\hline
\end{tabular}

*values that do not have common letters differ significantly for a statistical assurance level of $5 \%(\mathrm{P} \leq 0.05)$

\section{Insects density}

Insect's density was high in each year of experiment, ranging from 3.5 to 15.9 insects $/ \mathrm{m}^{2}$. Due to the fact that the experience was done in maize after maize and experimental plot had pea strips (plant with repellent effect for maize leaf weevil), the maximum number of insects was about 3 times higher than the economic damage threshold for Tanymecus (5 insects $/ \mathrm{m}^{2}$ ) (Table 4). As a result, there is a direct correlation between the application of insecticides, and the number of insects per square meter. The smallest number of insects present was registered for neem oil treatment. An intermediate value was recorded for the other two variants of the seed treatment. For vegetation treatments, the average values were high, between 9.6 and 10.55 insects $/ \mathrm{m}^{2}$, close to the control variants. This was due in particular to the high temperatures of the last few years of spring without the precipitation and rotation of maize after maize, which was favorable for the development of the pest.

Table 4. Density of Tanymecus dilaticollis (insects $\left./ \mathrm{m}^{2}\right)$ (2016-2018)

\begin{tabular}{|l|l|l|l|l|}
\hline $\begin{array}{l}\text { Treatment } \\
\text { application }\end{array}$ & Active substance/commercial product & Minimum & Maximum & Average \\
\hline Untreatment plot & Control & 5.9 & 15.9 & 10.9 \\
\hline \multirow{2}{*}{$\begin{array}{l}\text { Seed } \\
\text { treatment }\end{array}$} & Neem oil, 2.5 mL/250 g & 3.5 & 9.3 & 6.4 \\
\cline { 2 - 5 } & Spinosad, 2.5 mL/250 g & 4.2 & 12.1 & 8.15 \\
\cline { 2 - 5 } & $54 \%$ Bacillus thuringiensis, $0.01 \%$ & 5.2 & 12.9 & 9.05 \\
\hline \multirow{2}{*}{$\begin{array}{l}\text { Vegetation } \\
\text { treatment }\end{array}$} & Neem oil, 250 mL/ha & 5.5 & 15.6 & 10.55 \\
\cline { 2 - 5 } & Spinosad, 250 mL/ha & 5 & 14.3 & 9.65 \\
\cline { 2 - 5 } & $54 \%$ Bacillus thuringiensis, $0.01 \%$ & 5.5 & 13.7 & 9.6 \\
\hline
\end{tabular}

\section{Attack intensity}

The lowest number of insects was recorded in seed treatment with neem oil, so the intensity of the attack was the lowest of 3.72. By comparison, the highest intensity of the attack was recorded in Bacillus thuringiensis treated on seed, where mean values was similar to the control variant, of 5.50. At the same time, it is noted that the highest values of the attack intensity were recorded in the years 2017 and 2018. These years were favorable for Tanymecus dillaticolis attack, by high temperatures and without precipitation in April-May. 
Table 5. Attack intensity (2016-2018)

\begin{tabular}{|l|l|c|c|c|c|}
\hline \multirow{2}{*}{$\begin{array}{l}\text { Treatment } \\
\text { application }\end{array}$} & Active substance/commercial product & \multicolumn{3}{|c|}{ Years } & \multirow{2}{*}{ Average } \\
\cline { 2 - 5 } & & $\mathbf{2 0 1 6}$ & $\mathbf{2 0 1 7}$ & $\mathbf{2 0 1 8}$ & \\
\hline Untreatment plot & Control & 5.80 & 6.20 & 5.80 & 5.90 \\
\hline \multirow{3}{*}{ Seed treatment } & Neem oil, 2.5 ml/250 g & 3.70 & 3.85 & 3.60 & 3.72 \\
\cline { 2 - 5 } & Spinosad, 2.5 ml/250 g & 4.80 & 5.75 & 5.55 & 5.37 \\
\cline { 2 - 6 } & 54\% Bacillus thuringiensis, 0.01\% & 5.80 & 5.05 & 5.05 & 5.30 \\
\hline \multirow{2}{*}{$\begin{array}{l}\text { Vegetation } \\
\text { treatment }\end{array}$} & Neem oil, 250 ml/ha & 4.75 & 6.00 & 5.75 & 5.50 \\
\cline { 2 - 6 } & Spinosad, 250 ml/ha & 5.50 & 5.00 & 5.50 & 5.33 \\
\cline { 2 - 6 } & 54\% Bacillus thuringiensis, 0.01\% & 5.40 & 5.20 & 5.40 & 5.33 \\
\hline LSD P=.05 & 0.333 & 0.333 & 0.351 & 0.350 \\
\hline Standard Deviation (SD) & 0.224 & 0.224 & 0.237 & 0.236 \\
\hline Variation coefficient (CV) & 4.390 & 4.390 & 4.660 & 4.500 \\
\hline Replicate F & 0.695 & 0.695 & 0.648 & 1.404 \\
\hline Replicate Prob (F) & 0.5668 & 0.5668 & 0.5945 & 0.2741 \\
\hline Treatment F & 45.297 & 45.297 & 43.069 & 41.940 \\
\hline Treatment Prob (F) & 0.0001 & 0.0001 & 0.0001 & 0.0001 \\
\hline
\end{tabular}

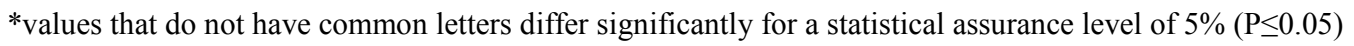

Analyzing the data in Table 5, it was found that under the conditions of 2016, the lowest attack of $T$. dilaticollis was recorded in the case of the seed treated with neem oil and also vegetation treatment.

In the climatic conditions of 2017, in the experimental field at INCDA Fundulea, it was found that under the conditions of a moderate attack of Tanymecus dilaticollis, there are no statistical differences between the variants treated in vegetation with spinosad and Bacillus turingiensis $(\mathrm{P}<.05)$.

In 2018, the $T$. dilaticollis attack on untreated plants was moderate $(I=5.8)$. With the exception of the single dose variant with neem oil, among the other variants there were no statistically differences of the attack intensity $(\mathrm{P}<.05)$.

Analyzing the three-year data (2016-2018), in all three years of experimentation, the lowest attack was in the case of neem oil apllyed on seeds.

\section{Percentage of saved plants}

Regarding the percentage of saved plants, in the year 2016, in the experimental field at NARDI Fundulea, it was found that the seeds treatments variants was higher at neem oil treatment $(82.78 \%$ ) (Table 6).

Table 6. Saved plants (\%) (2016-2018)

\begin{tabular}{|l|l|l|l|l|l|}
\hline \multirow{2}{*}{$\begin{array}{l}\text { Treatment } \\
\text { application }\end{array}$} & $\begin{array}{l}\text { Active substance/commercial } \\
\text { product }\end{array}$ & \multicolumn{3}{|c|}{ Years } & \multirow{2}{*}{ Average } \\
\cline { 2 - 6 } & $\mathbf{2 0 1 6}$ & $\mathbf{2 0 1 7}$ & $\mathbf{2 0 1 8}$ & \\
\hline Untreatment plot & Control & $52.78 \mathrm{e}$ & $65.00 \mathrm{e}$ & $71.68 \mathrm{~d}$ & 63.15 \\
\hline \multirow{4}{*}{ Seed treatment } & Neem oil, 2.5 mL/250 g & $82.78 \mathrm{a}$ & $79.44 \mathrm{a}$ & $81.69 \mathrm{a}$ & 81.30 \\
\cline { 2 - 6 } & Spinosad, 2.5 mL/250 g & $81.67 \mathrm{a}$ & $78.89 \mathrm{ab}$ & $77.39 \mathrm{c}$ & 79.31 \\
\cline { 2 - 6 } & $\begin{array}{l}54 \% \text { Bacillus thuringiensis, } \\
0.01 \%\end{array}$ & $67.78 \mathrm{~d}$ & $78.89 \mathrm{ab}$ & $78.27 \mathrm{c}$ & 74.98 \\
\hline $\begin{array}{l}\text { Vegetation } \\
\text { treatment }\end{array}$ & Neem oil, 250 mL/ha & $72.78 \mathrm{c}$ & $70.00 \mathrm{~d}$ & $77.44 \mathrm{c}$ & 73.40 \\
\cline { 2 - 6 } & Spinosad, 250 mL/ha & $79.78 \mathrm{~b}$ & $77.44 \mathrm{bc}$ & $79.75 \mathrm{~b}$ & 78.99 \\
\cline { 2 - 6 } & $\begin{array}{l}54 \% \text { Bacillus thuringiensis, } \\
\text { 0.01\% }\end{array}$ & $78.67 \mathrm{~b}$ & $76.89 \mathrm{c}$ & $77.63 \mathrm{c}$ & 77.73 \\
\hline LSD P=.05 & 1.459 & 1.459 & 1.459 & 1.383 \\
\hline Standard Deviation (SD) & 0.982 & 0.982 & 0.982 & 0.931 \\
\hline Variation coefficient (CV) & 1.33 & 1.33 & 1.33 & 1.24 \\
\hline Replicate F & 1.328 & 1.328 & 1.328 & 0.119 \\
\hline Replicate Prob (F) & 0.2964 & 0.2964 & 0.2964 & 0.9479 \\
\hline Treatment F & 470.786 & 470.786 & 470.786 & 141.763 \\
\hline Treatment Prob (F) & 0.0001 & 0.0001 & 0.0001 & 0.0001 \\
\hline
\end{tabular}

*values that do not have common letters differ significantly for a statistical assurance level of $5 \%(\mathrm{P} \leq 0.05)$ 
This variant for all tree years of experiment has the highest level of statistical significance, the differences from the untreated variant being significant. In the variants where treatments were applied in the vegetation, although there are statistical differences from the control variant. The differences are smaller compared to those recorded in the treatments applied to the seed and compared to the control variant.

In 2017, the percentage of saved plants in the control variant was $65.00 \%$, higher than in the control variant in 2016. The largest statistically differences were recorded between the seeds treated with neem oil and the untreated variant, followed by the variant where the seeds were treated with spinosad and Bacillus turingiensis in vegetation $(\mathrm{P}<.05)$.

In 2018, in the control variant, the percentage of saved plants was $71.68 \%$. These differences, compared to those recorded in 2016, were due to the excess rainfall registered in 2018, especially in June. This year, the largest statistical difference compared to the control was recorded for the variant where the seeds were treated with neem oil, followed by the variant with Spinosad and Bacillus turingiensis in vegetation. The variants with spinosad and Bacillus turingiensis applied to seeds had the same level of statistical significance, but the differences from the untreated control were smaller than in other cases. High values were also obtained in the treatment with neem oil at seed and vegetation (78.99 to $79.31 \%$ ).

In all three years of experimentation, the most stable significant difference from the untreated control was recorded in using of neem oil treatment.

In the climatic conditions of 2016, the correlation between the intensity of the $T$. dilaticollis attack and the percentage of saved plants was negative (Figure 1).

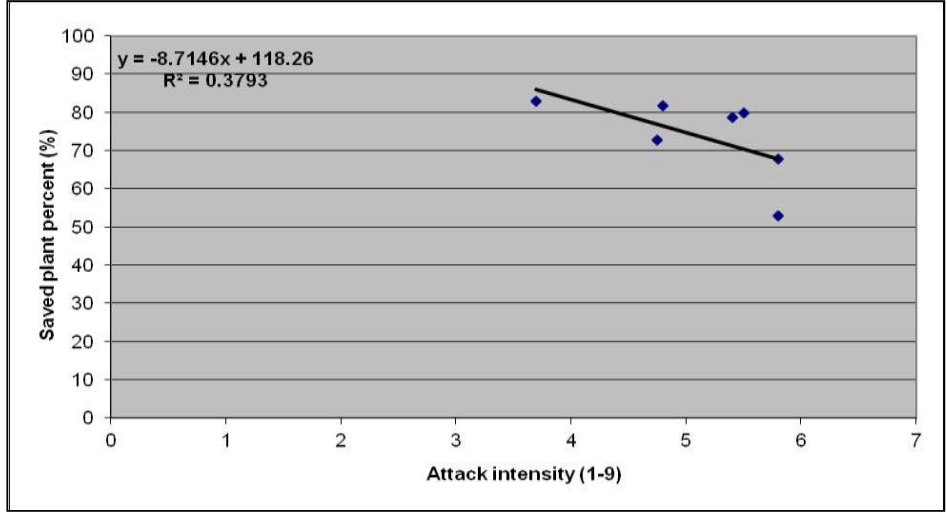

Figure 1. Correlation between attack intensity and number of saved plants in 2016 .

A similar situation was recorded in the climatic conditions of 2017 , while in 2018 , although the correlation was negative, the relationship between the intensity of the attack and the percentage of the saved plants was not so tight (Figure 2 and Figure 3).

In the case of attack intensity, the percentage of lost plants is directly and significantly influenced when the number of insects increases. It is increasing directly in proportion to the increase in intensity attack.
It is worth noting that the number of insects under control was 3 times higher $\left(15.9\right.$ insects $\left./ \mathrm{m}^{2}\right)$ than the economic damage threshold, for this pest $\left(5\right.$ insects $\left./ \mathrm{m}^{2}\right)$. The density of insects was high, very close to the control, and in the case of vegetation treatment with neem oil $\left(15.6\right.$ insects $\left./ \mathrm{m}^{2}\right)$. The best efficiency, significant, was achieved by applying this product to the seed.

The difference between the two graduations taken in monitoring (treated seeds, respectively untreated seeds) is provided statistically.

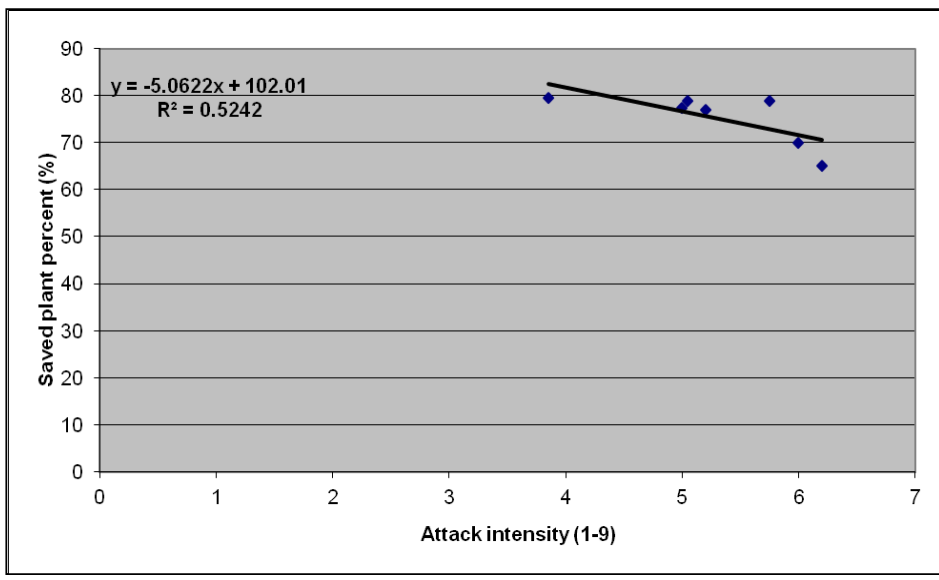

Figure 2. Correlation between attack intensity and number of saved plants in 2017. 


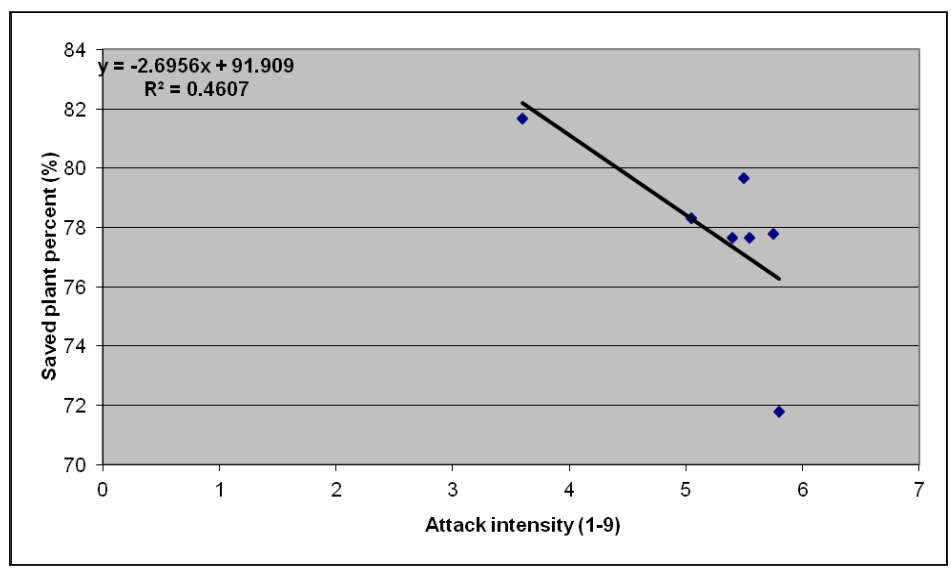

Figure 3. Correlation between attack intensity and number of saved plants in 2018.

\section{Conclusion}

Due to large areas, maize is commonly grown on the same plot many years, sometimes 4-5 years, which may increase the multiplication of pest populations, including Tanymecus dilaticollis, considered to be the most harmful pest for maize crops (but also for sunflower or sugar beet).

As a result, to reduce the damage caused by this pest, it is necessary to treat the seeds with insecticides before sowing and sometimes treatment interventions are necessary at the beginning of the vegetation period.

But, in organic agriculture the solutions of maize leaf weevil control are limited, according by legislation.

These results demonstrate a moderate efficacy of some alternatives insecticides for organic agriculture on Tanymecus dilaticollis pest control for using in Romania.

Insecticides applied to the seed, based on neem oil, provided a good protection for maize plants against T. dilaticollis, with an average of $81.30 \%$ saved plants.

Also, the vegetation treatments are noted for the application of spinosad with $78.99 \%$ and Bacillus turingiensis with the percentage of plants saved $78.00 \%$.

In conclusion, under variable climatic conditions from one year to another, these results demonstrate the a moderate efficacy of some alternatives insecticides for organic agriculture on Tanymecus dilaticollis pest control for using in Romania, especially neem oil that can be used for seed treatment.

\section{References}

1. A. BARBUlesCU, I. VOINESCU, D. SADAGORSCHI, A. PENESCU, C. POPOV, S. VASILESCU. Cruiser 350 FS-A new product for maize and sunflower seed treatment against Tanymecus dilaticollis Gyll. Romanian Agricultural Research, 15: 77-87 (2001).

2. D.S. ČAMPRAG, R.R. SECULIC, T.B. KEREŠI. Forecasting of major sugar beet pest occurrence in
Serbia during the period 1961-2004. Proc. Natl. Sci. Matica Srpska NoviSad,110, 187-194 (2006).

3. EUROPEAN AND MEDITERRANEAN PLANT PROTECTION ORGANIZATION. Guidelines on good plant protection practice. https://www.eppo.int/ RESOURCES/eppo_standards/pp2_gpp (1999).

4. THE FOOD AND AGRICULTURE ORGANIZATION OF THE UNITED NATIONS WEbsite, available at: http://www.fao.org. (2020).

5. L. GERGINOV. Insect pests of maize in Bulgaria and their control. Acta Phytopathologica et Entomologica Hungarica, 24, 81-84 (1989).

6. E. GEORGESCU, L. CANA, C. POPOV, R. GARGARITA, L. RASNOVEANU, L. VOINEA. Maize leaf weevil (Tanymecus dilaticollis Gyll.) in the context of neonicotinoid seed treatment restriction. Annals of NARDI Fundulea, 82:251-277 (2014).

7. E. GEORGESCU, L. CANA, R. GARGARITA, L. VOINEA, L RASNOVEANU. Atypically behaviour of the maize leaf weevil (Tanymecus dilaticollis Gyll.) on maize and sunflower crops, in climatic conditions of the year 2014, in South-East of Romania. Agriculture and Agricultural Science Procedia, 6:9-16 (2015).

8. E. GEORGESCU, M. TOADER, A.M. IONESCU, L. CANA, L. RASNOVEANU. Testing of the new insecticides formulation for maize seeds treatment against Tanymecus dilaticollis Gyll. in laboratory conditions. AgroLife Scientific Journal, 5(1):83-90 (2016).

9. JOURNAL GENERAL DE L'EUROPE. SBM Développement France has proposed in Romania an alternative technology to protect the maize and sunflower crops against Tanymecus dillaticolis, a dangerous regional soil insect. https://www.journal generaldeleurope.org/en/article dossier/sbm-developp ement-france/ (2020).

10. A. KACSÓ. Damage caused by Tanymecus dilaticollis Gyll. to leaf and crop. Acta Agronomica Academiae 
Scientiarum Hungaricae, 23(3/4), 285-303 (1974).

11. S. KESZTHELYI, P. KURUCSAI, T. SZABÓ, F. PÁL-FÁM, Z. MARCZALI. Chemical protections against corn weevil (Tanymecus dilaticollis Gyll.) on different soil types. VII. Alps-Adria Scientific Workshop, Stara Lesna, Slovakia, 1:191-194 (2008).

12. K. KIRKOV. Tanymecus dilaticollis-its biology and control. Rastenievadni Nauki, 6, 45-50 (1967).

13. H. KRUSTEVA, M. PANAJOTOVA, T. TONEV, Y. KARADZHOVA, S. MILANOVA, P. NIKOLOV, A. VELICHKOV. Good plant protection practice in maize crops. Ministry of Agriculture and Food, Sofia, 2, 015, 1, 69-77 (2006).

14. INTERACTIVE AGRICULTURAL ECOLOGICAL ATLAS OF RUSSIA AND NEIGHBORING COUNTRIES (AGROATLAS). Economic Plants and their Diseases, Pests and Weeds. http://www. agroatlas. ru/en/80/ pests/ index. html (2020).

15. MADR. MINISTRY OF AGRICULTURE AND RURAL DEVELOPMENT OF ROMANIA, available at: http://www.madr.ro/culturi-de-camp/cereale/ porumb.htm.l. (2020).

16. E. PARTAL, G.V. ZAHARIA. Results on the effects of fertilization on the main field crops. Anals of NARDI Fundulea. Vol. LXXIV:111-118 (2008).

17. F. PAULIAN. Contribution at knowledge of the development, ecology and control of the Tanymecus dilaticollis specie. Doctoral thesis, I.A.N.B. Bucharest, p. 300 (1972).

18. F. PAULIAN, C. POPOV, D. P. MARCELA. The corn leaf weevil (Tanymecus dillaticolis Gyll.) in Romania and its control. Contemporary Agriculture, 5-6:643652 (1969).

19. C. POPOV, A. BARBULESCU. 50 years of scientific activity in field crop protection area, against pests and diseases. Annals of NARDI Fundulea, 75:371-404 (2007).

20. G. SÁRINGER, A. TAKÁCS. Biology and control of Tanymecus dilaticollis Gyll. (Col., Curculionidae). Acta Phytopatologica et Entomologica Hungarica, 29(1-2), 173-185 (1994).

21. M. TOADER, E. GEORGESCU, A. M. IONESCU. The insecticides effectiveness on Tanymecus dilaticollis attack on maize at NARDI Fundulea. http://www.sciencedirect.com/science/article/pii/ $\underline{\text { S2210784316301991 (2016). }}$.

22. I. VOINESCU. Maize seed treatments with carbamic insecticides, effective method of $T$. dilaticollis Gyll. controll. Problems of Plant protection, 13(2):151-156 (1985).

23. H. WILLER, D. SCHAACK, J. LERNOUD. Organic Farming and Market Development in Europe and the European Union. Available at: http://orgprints.org/ 31187/1/willer-etal-2017-europe.pdf (2020). 